\title{
COGNITIVE AND PSYCHOTIC SYMPTOMS IN A PATIENT WITH INFRATENTORIAL ARACHNOID CYST: CASE REPORT
}

\author{
Maja Škarić1, Branka Aukst Margetićc ${ }^{2}$ Anamarija Bogović Dijaković and Dalibor Karlović \\ ${ }^{1}$ Department of Psychiatry, Dr. Ivan Barbot Neuropsychiatric Hospital, Popovača, Croatia; \\ ${ }^{2}$ Department of Psychiatry, Sestre milosrdnice University Hospital Centre, Zagreb, Croatia
}

\begin{abstract}
SUMMARY - We present a case of a patient with treatment resistant hallucinatory experiences with incidental finding of an arachnoid cyst localized in the posterior infratentorial cranial fossa dorsally to the cerebellum. Psychological testing revealed significant deficit of cognitive functions to the level of mild intellectual disability in a person that had previously finished high school with good grades. A combination of clozapine and lamotrigine led to significant improvement in mood and reduction of hallucinations, but without improvement in cognitive functions. We also performed a literature review of previously published case reports or case series of co-occurring posterior fossa arachnoid cyst and schizophrenia or psychosis or psychiatric symptoms using PubMed search and discuss some controversies considering their treatment outcome.
\end{abstract}

Key words: Arachnoid cyst; Cognitive disorder; Psychotic symptoms

\section{Introduction}

Arachnoid cysts are benign lesions formed by arachnoid membrane filled with liquid similar to cerebrospinal fluid. Their prevalence goes to $1.4 \%$, it is higher in male gender, and their detection is usually incidental. The most common location is middle fossa, followed by retrocerebellar and convexity ${ }^{1}$. It appears that symptoms caused by an arachnoid cyst depend on the intracystic pressure, where high intracystic pressure had a significantly higher preoperative level of complaints $^{2}$. Functional imaging has shown that arachnoid cysts may cause reorganization of cortical functions and reduced cortical thickness of neighboring cortices ${ }^{3}$. It has been reported that arachnoid cyst reduces perfusion and metabolism in the surrounding cortical regions ${ }^{4,5}$. The reports published so far do suggest that arachnoid cyst may affect mental functions $\mathrm{s}^{6,7}$,

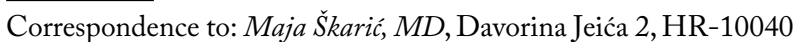

Zagreb, Croatia

E-mail: maja.skaric@gmail.com

Received October 15, 2019, accepted August 20, 2020 such as affective disorders ${ }^{8}$, psychotic symptoms in the form of hallucinations and delusions ${ }^{9,10}$, and even aggression and homicide ${ }^{11}$. Dyscognition as a symptom has been described in several case reports on arachnoid cyst patients. In recent years, increasing attention is paid to cognitive disorders accompanying arachnoid cysts $^{12-15}$. Psychiatric symptoms and dyscognition usually are not an indication for neurosurgical intervention. However, there are reports that describe normalized mental functions after surgical cyst decompres$\operatorname{sion}^{12-15}$. The aim of this case report is to describe a patient with a rare location of arachnoid cyst, presented with isolated imperative hallucinations of compulsory nature, and to discuss his treatment, as well as the potential treatment approaches.

\section{Case Report}

A 22-year-old male Caucasian was admitted to day hospital treatment for complaining of imperative auditory hallucinations as an isolated psychotic symptom. Three years before, he started to hear unknown 
voice in his head telling him to check if the water was leaking. He knew that it was not real but still had to do it. He felt that the voice was coming 'from his small brain', and that 'in his head he was not himself'. The patient was born at term but was small for gestational age, birth weight of only $1900 \mathrm{~g}$ due to maternal hypertension during pregnancy. For a short time, he was treated in the neonatal intensive care unit. His development during the first year of life was checked with brain ultrasound, his further development was regularly checked and evaluated as normal. He graduated from primary and high school with good grades. His symptoms started in the last year of high school and coincided with death of his grandmother he was closely bonded to. He was described by his parents as timid and shy, having few friends. After finishing high school he started to work as a waiter but three months later quit his job because it was too stressful. Later he did not search for new employment. There was no known family history of a psychiatric disorder. Ten months before admission to the hospital, he started outpatient psychiatric treatment during which he received different psychopharmaceuticals (olanzapine $10 \mathrm{mg} / \mathrm{d}$ for three months, later switched to a combination of risperidone $4 \mathrm{mg} / \mathrm{d}$, fluvoxamine $100 \mathrm{mg} / \mathrm{d}$ for another three months, later switched to a combination of vortioxetin $10 \mathrm{mg} / \mathrm{d}$ and aripiprazole $30 \mathrm{mg} / \mathrm{d}$ ), all with no improvement. Upon admission to the hospital, he underwent psychological testing and magnetic resonance imaging (MRI) of the brain. Physical and neurological examination showed no abnormalities. Visual, auditory and somatosensory evoked potentials, as well as examination of the fundus oculi revealed no pathology. Psychological testing (BETA-II, WMS, Cornell index, WDCT, mosaic test, WCST) revealed deficit in logical thinking, learning ability and mental control, as well as impairment in executive functions. His intellectual efficacy, psychomotor speed and memorizing ability were decreased to the level of mild intellectual disability, and his concrete and abstract thinking to the level of moderate intellectual disability. At admission, his psychopathology was evaluated with Positive and Negative Syndrome Scale (PANSS) and scored 86, while Calgary Depression Scale showed a score of 7 points. MRI $(2.0 \mathrm{~T})$ of his central nervous system showed an arachnoid cyst in the posterior cranial fossa, infratentorial dorsally to the cerebellum, $6.3 \times 5.9 \times 4.4 \mathrm{~cm}$ in size (Fig. 1). Regular neurosurgery

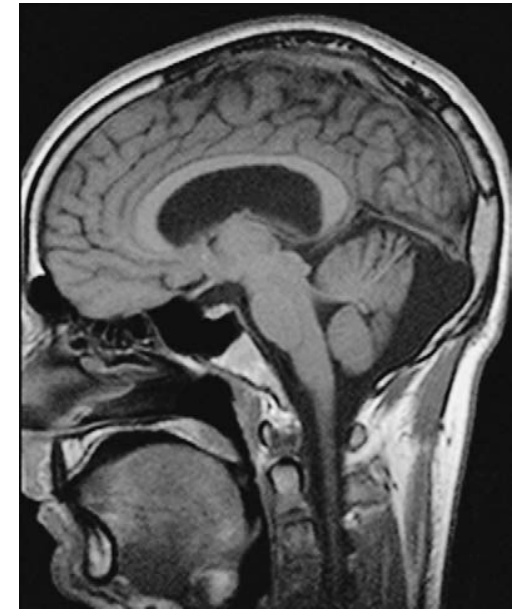

Fig. 1. Magnetic resonance image (2.0 T) of the arachnoid cyst $(6.3 \times 5.9 \times 4.4 \mathrm{~cm}$ in size) in the posterior cranial fossa.

follow-up was recommended. The administration of clozapine $125 \mathrm{mg} /$ day, lamotrigine $100 \mathrm{mg} /$ day and diazepam $5 \mathrm{mg} /$ day led to gradual but significant improvement of mood and reduction of hallucinations. On follow-up examination three months after treatment initiation, the patient reported the voice appearing from time to time, about three to four times a week, lasting for 10-15 minutes, he was less emotionally engaged about it and could disregard it almost completely. The PANSS decreased to 55 and Calgary Depression Scale to 0 . He was more engaged in social contacts and worked in family business. At ninemonth follow-up evaluation, the PANSS decreased to 52 and Calgary Depression Scale score was 0. The frequency of voice appearing decreased further to three to four times a week, lasting for a few minutes, and he could disregard the voices completely. Psychological testing (BETA-II, WMS, Cornell index, mosaic test) was repeated after 9 months and showed some improvement in mental control and concrete and abstract thinking; other findings where the same as before.

\section{Discussion}

For many years, the basis for a whole palette of schizophrenia spectrum symptoms has been associated with supratentorial structures. However, newer findings suggest an important role of cerebellum in their development ${ }^{16}$. In other words, in a patient suffering from schizophrenia, error detection task of the cere- 
bellum is impaired, so an auditory signal arising from the auditory cortex without an external stimulus is misinterpreted and experienced as auditory hallucination. Also, the importance of the right cerebellum in language processing has been shown by previous studies. Structural MRI study in patients with treatment resistant auditory verbal hallucinations has shown decreased gray matter volume in the right cerebellar hemisphere in the regions involved in different cognitive and language processes ${ }^{17}$. Our patient described hearing a voice with a quality of imperative auditory hallucination (to check if the water was leaking) and although he had an insight, he could not resist obeying the command. It is possible that the patient's cerebellar lesion was superimposed on an underlying psychiatric disorder and that the brain lesion was an incidental finding without functional importance. However, we cannot exclude the possibility that the arachnoid cyst located dorsally to the cerebellum caused thinning of the adjacent cortex and reorganization of cortical functions ${ }^{3}$. So, it is possible to assume that pressure from the cyst may have caused malfunction of the cerebellum error detection task, which led to his experience of auditory hallucination. In addition, when the cerebellum fails to perform its error detection function, cognitive impairment is present $t^{16}$. Our patient's intellectual efficacy and psychomotor speed were reduced to the level of mild intellectual disability with concrete and abstract thinking at the level of moderate intellectual disability. One might assume that a person with such cognitive abilities would not be able to finish primary and high school with moderately good grades. So, we may presume that cognitive deficit was the result of cyst enlargement and that during his years of schooling the cyst was smaller and did not cause any pressure on the surroundings, and therefore his cognitive symptoms where not present or at least not to such an extent. There is evidence that cysts may grow considerably in childhood, thus indicating an increasing intracystic pressure over time ${ }^{18}$. The association between arachnoid cysts at this localization and psychotic symptoms is poorly researched. We performed Medline search using the terms "arachnoid cyst" and "posterior fossa" or "cerebellar" and "schizophrenia", "psychiatric symptom" or "psychosis". Results are shown in Table 1. The issue of neurosurgical treatment of cysts is still debated among neurosurgeons, especially when they are asymptomatic in terms of neuro-
Table 1. Medline search: association between arachnoid cysts in the posterior fossa and psychotic symptoms

Wu YY, Shen YC. Delusions of control in a case of schizophrenia coexisting with a large cerebellar arachnoid cyst. Ci Ji Yi Xue Za Zhi. 2017;29(2): $115-7 .^{10}$

Heidrich A, Schmidtke A, Lesch KP, Hofmann E, Becker T. Cerebellar arachnoid cyst in a firesetter: the weight of organic lesions in arson. J Psychiatry Neurosci. 1996;21(3):202-6. ${ }^{19}$

Larysz D, Blamek S, Larysz P, Pietras K, Mandera M.

Posterior fossa brain tissue injury: developmental, neuropsychological, and neurological consequences of brain tumors in children. Acta Neurochir Suppl. 2010;106:271-4. ${ }^{20}$

Cuny ML, Pallone M, Piana H, Boddaert N, Sainte-Rose C, Vaivre-Douret L, Piolino P, Puget S. Neuropsychological improvement after posterior fossa arachnoid cyst drainage. Childs Nerv Syst.

2017;33(1):135-41. ${ }^{21}$

Maner F, Babalioglu M, Cetinkaya O, Ipekcioglu D, Ergen N, Yesil R, et al. The coexistence of arachnoid cyst with first episode psychosis: four cases. J Neurol Disord. 2014;2:186. ${ }^{22}$

Jurjus GJ, Weiss KM, Jaskiw GE. Schizophrenia-like psychosis and cerebellar degeneration. Schizophr Res. 1994;12(2):183-4. ${ }^{23}$

Ben Dahman A, David P, Massager N, Leistedt S, Loas G. A marsupialized retrovermian arachnoid cyst and psychotic symptoms. J Surg Case Rep.

2017;2017(8). ${ }^{24}$

Rabiei K, Hellström P, Högfeldt-Johansson M, Tisell M. Does subjective improvement in adults with intracranial arachnoid cysts justify surgical treatment? J Neurosurg. 2018;128(1):250-7..$^{25}$

Boltshauser E, Martin F, Altermatt S. Outcome in children with space-occupying posterior fossa arachnoid cysts. Neuropediatrics. 2002;33(3):118-21. ${ }^{26}$ Kalapatapu RK. Aripiprazole treatment of psychosis in a child with posterior fossa retrocerebellar arachnoid cyst. J Child Adolesc Psychopharmacol.

2009;19(3):321-5. ${ }^{27}$

Das S. Posterior fossa arachnoid cyst presenting as negative symptoms of psychosis. Shanghai Arch Psychiatry. 2018;30(3):202-3. ${ }^{28}$

Nakano H, Ogashiwa M. Complete remission of narcolepsy after surgical treatment of an arachnoid cyst in the cerebellopontine angle. J Neurol Neurosurg Psychiatry. 1995;58(2):264. ${ }^{29}$ 
logical symptoms. Nevertheless, evidence on the normalization of mental functions has been reported in some studies ${ }^{12-15}$. Operative cyst decompression is an option that still needs to be evaluated in larger studies. Psychotic symptoms treated with antipsychotic drugs in patients with brain malformations tend to show therapeutic resistance. Our patient was resistant to treatment with several antipsychotics and showed improvement when the reserve antipsychotic clozapine was introduced. Nevertheless, his cognitive symptoms were persistent and showed only slight improvement.

The outcome of operative treatment versus treatment with antipsychotics for arachnoid cysts presented with psychotic symptoms has never been evaluated and should be researched in further studies.

\section{References}

1. Al-Holou WN, Terman S, Kilburg C, Garton HJL, Muraszko KM, Maher CO. Prevalence and natural history of arachnoid cysts in adults. J Neurosurg. 2013;118:222-31. doi: 10.3171/ 2012.10.JNS12548

2. Helland CA, Wester K. Intracystic pressure in patients with temporal arachnoid cysts. A prospective study of pre-operative complaints and post-operative outcome. J Neurol Neurosurg Psychiatry. 2007;78:620-3. doi: 10.1136/jnnp.2006.101865

3. Hund-Georgiadis M, Yves von Cramon D, Kruggel F, Preul C. Do quiescent arachnoid cysts alter CNS functional organization? A fMRI and morphometric study. Neurology. 2002; 59:1935-9. doi: 10.1212/01.WNL.0000038745.98689.6B

4. De Volder AG, Michel C, Thauvoy C, Willems G, Ferrière G. Brain glucose utilisation in acquired childhood aphasia associated with a sylvian arachnoid cyst: recovery after shunting as demonstrated by PET. J Neurol Neurosurg Psychiatry. 1994; 57(3):296-300. doi: 10.1136/jnnp.57.3.296

5. Sgouros S, Chapman S. Congenital middle fossa arachnoid cysts may cause global brain ischaemia: a study with $99 \mathrm{Tc}^{-}$ hexamethylpropyleneamineoxime single photon emission computerised tomography scans. Pediatr Neurosurg. 2001;35 (4):188-94. doi: 10.1159/000050420

6. Kohn R, Lilly RB, Sokol MS, Malloy PF. Psychiatric presentations of intracranial cysts. J Neuropsychiatry Clin Neurosci. 1989;1(1):60-6. doi: 10.1176/jnp.1.1.60

7. Wester K. Intracranial arachnoid cysts - do they impair mental functions? J Neurol. 2008;255:1113-20. doi: 10.1007/s00415008-0011-y

8. Vidrih B, Karlovic D, Bosnjak Pasic M. Arachnoid cyst as the cause of bipolar affective disorder: case report. Acta Clin Croat. 2012;51:655-9. https://hrcak.srce.hr/108098

9. Alves da Silva J, Alves A, Talina M, Carreiro S, Guimarães J, Xavier M. Arachnoid cyst in a patient with psychosis: case re- port. Ann Gen Psychiatry. 2007;6:16-21. doi: 10.1186/1744859X-6-16

10. Wu YY, Shen YC. Delusions of control in a case of schizophrenia coexisting with a large cerebellar arachnoid cyst. Ci Ji Yi Xue Za Zhi. 2017;29:115-7. doi: 10.4103/tcmj.tcmj_23_17

11. Margetic B, Zarkovic Palijan T, Kovacevic D. Homicide and subsequent catatonia associated with a large arachnoid cyst: case report. Acta Clin Croat. 2013;52:497-505. https://hrcak. srce.hr/122563

12. Raeder MB, Helland CA, Hugdahl K, Wester K. Arachnoid cysts cause cognitive deficits that improve after surgery. Neurology. 2005;64(1):160-2. doi: 10.1212/01.WNL.00001487 24.61966.A4

13. Wester K, Hugdahl K. Arachnoid cysts of the left temporal fossa: impaired preoperative cognition and postoperative improvement. J Neurol Neurosurg Psychiatry. 1995;59(3):293-8. doi: 10.1136/jnnp.59.3.293

14. Gjerde PB, Schmid M, Hammar A, Wester K. Intracranial arachnoid cysts: impairment of higher cognitive functions and postoperative improvement. J Neurodev Disord. 2013;5:21. doi: 10.1186/1866-1955-5-21

15. Torgersen J, Helland C, Flaatten H, Wester K. Reversible dyscognition in patients with a unilateral, middle fossa arachnoid cyst revealed by using a laptop based neuropsychological test battery (CANTAB). J Neurol. 2010;257(11):1909-16. doi: 10.1007/s00415-010-5634-0

16. Andreasen NC, Pierson R. The role of the cerebellum in schizophrenia. Biol Psychiatry. 2008;64:81-8. doi: 10.1016/j. biopsych.2008.01.003

17. Cierpka M, Wolf ND, Kubera KM, Schmitgen MM, Vasic N, Frasch K, Wolf RC. Cerebellar contributions to persistent auditory verbal hallucinations in patients with schizophrenia. Cerebellum. 2017;16:964-72. doi: 10.1007/s12311-017-0874-5

18. Wester K. Arachnoid Cysts: Epidemiology, Biology, and Neuroimaging, Vol. 1., London: Academic Press, 2017;67-72.

19. Heidrich A, Schmidtke A, Lesch KP, Hofmann E, Becker T. Cerebellar arachnoid cyst in a firesetter: the weight of organic lesions in arson. J Psychiatry Neurosci. 1996;21(3):202-6. PMID:8935333

20. Larysz D, Blamek S, Larysz P, Pietras K, Mandera M. Posterior fossa brain tissue injury: developmental, neuropsychologi$\mathrm{cal}$, and neurological consequences of brain tumors in children. Acta Neurochir Suppl. 2010;106:271-4. doi: 10.1007/978-3211-98811-4_51

21. Cuny ML, Pallone M, Piana H, Boddaert N, Sainte-Rose C, Vaivre-Douret L, Piolino P, Puget S. Neuropsychological improvement after posterior fossa arachnoid cyst drainage. Childs Nerv Syst. 2017;33(1):135-41. doi: 10.1007/s00381-016-3285-x

22. Maner F, Babalioglu M, Cetinkaya O, Ipekcioglu D, Ergen N, Yesil R, et al. The coexistence of arachnoid cyst with first episode psychosis: four cases. J Neurol Disord. 2014;2:186. doi: 10.4172/2329-6895.1000186

23. Jurjus GJ, Weiss KM, Jaskiw GE. Schizophrenia-like psychosis and cerebellar degeneration. Schizophr Res. 1994;12(2):183-4. doi: 10.1016/0920-9964(94)90076-0 
24. Ben Dahman A, David P, Massager N, Leistedt S, Loas G. A marsupialized retrovermian arachnoid cyst and psychotic symptoms. J Surg Case Rep. 2017;2017(8). doi: 10.1093/jscr/rjx162

25. Rabiei K, Hellström P, Högfeldt-Johansson M, Tisell M. Does subjective improvement in adults with intracranial arachnoid cysts justify surgical treatment? J Neurosurg. 2018;128(1): 250-7. doi 10.3171/2016.9.JNS161139

26. Boltshauser E, Martin F, Altermatt S. Outcome in children with space-occupying posterior fossa arachnoid cysts. Neuropediatrics. 2002;33(3):118-21. doi: 10.1055/s-2002-33674
27. Kalapatapu RK. Aripiprazole treatment of psychosis in a child with posterior fossa retrocerebellar arachnoid cyst. J Child Adolesc Psychopharmacol. 2009;19(3):321-5. doi: 10.1089/ cap.2008.077

28. Das S. Posterior fossa arachnoid cyst presenting as negative symptoms of psychosis. Shanghai Arch Psychiatry. 2018;30(3): 202-3. doi: 10.11919/j.issn.1002-0829.218005

29. Nakano H, Ogashiwa M. Complete remission of narcolepsy after surgical treatment of an arachnoid cyst in the cerebellopontine angle. J Neurol Neurosurg Psychiatry. 1995;58(2):264. doi: 10.1136/jnnp.58.2.264

Sažetak

\section{KOGNITIVNI I PSIHOTIČNI SIMPTOMI KOD BOLESNIKA S INFRATENTORIJALNOM ARAHNOIDNOM CISTOM: PRIKAZ SLUČAJA}

\section{M. Škarić, B. Aukst Margetic, A. Bogović Dijaković i D. Karlović}

Prikazuje se slučaj bolesnika sa slušnim halucinacijama kod kojega je kao slučajan nalaz pronađena arahnoidna cista lokalizirana infratentorijalno u stražnjoj lubanjskoj jami dorzalno od cerebeluma. Psihologijsko testiranje je otkrilo značajan deficit kognitivnih funkcija do razine umjerenih intelektualnih poteškoća, iako je prethodno završio srednju školu s dobrim uspjehom. Kombinacija klozapina i lamotrigina je dovela do značajnog poboljšanja u raspoloženju i do smanjenja halucinacija, no nije došlo do poboljšanja kognitivnih funkcija. Pregledali smo PubMed tražeći objavljene slučajeve bolesnika s arahnoidnom cistom u stražnjoj lubanjskoj jami i koincidirajućim psihijatrijskim simptomima te raspravili neke kontroverzije vezane uz ishod liječenja takvih bolesnika.

Ključne riječi: Arahnoidna cista; Kognitivni poremećaj; Psihotični simptomi 